DOI: $10.35681 / 1560-9189.2021 .23 .3 .244796$

УДК 004.82

I. О. Храмова

Інститут проблем реєстрації інформації НАН України вул. М. Шпака, 2, 03113 Київ, Україна

\title{
Підтримка цілісності семантичного шару загального інформаційного простору корпоративних інтелектуальних систем
}

\begin{abstract}
Розглянуто деякі аспекти актуалізації семантичного контексту для спільного інформаційного простору корпоративних інтелектуальних систем. Динамічний світ спонукає модифікувати існуючу семантичну модель такої системи відповідно до безперервних змін, щчо важко зробити вручну, оскільки семантику такого інформачійного простору часто представлено набором онтологій $і$ їхніми взаємними відображеннями. Існують певні проблеми підтримки иілісності семантичної моделі, щуо пов'язані зі змінами, оскільки елементарний процес зміни може викликати інше завдання зміни або навіть послідовність таких завдань. У роботі розглянуто такі питання як джерела та види змін в онтологічних моделях, визначено основні завдання, які виконуються в прочесі внесення змін. Також надано перелік існуючих методів і підходів до виконання тих чи інших завдань.
\end{abstract}

Ключові слова: інтеграція даних, корпоративна інтелектуальна система, онтологічна модель, семантична узгодженість.

\section{Постановка проблеми}

Інтероперабельність і семантична узгодженість різнорідних компонентів, що формують загальний інформаційний простір сучасних корпоративних інтелектуальних систем (КІС), грунтується на онтологічних моделях предметної області (ПрО). Ці моделі містять відповідні ПрО сукупності понять, співвідношення між окремими поняттями та екземплярами цих понять [1-8]. Часто онтології КІС приймають форму тезаурусів або термінологічних словників [9].

Компоненти IT-архітектури КIC, або, як їх ще можна назвати, IT-ресурси, в свою чергу, можуть мати власні часткові онтології, деякі з них з'являються вже на етапі розгортання, впровадження або експлуатації КIC, а надалі відображаються на існуючу загальну (корпоративну або загальновживану) формальну онтологічну модель, тим самим доповнюючи або, навіть, змінюючи іiі [10-12]. Сукупність таких 
моделей і їхніх взаємних відображень будемо розглядати як семантичний шар загального інформаційного простору КIC.

Динаміка змін у часі IT-ресурсів існуючого екземпляру IT-архітектури КIC за умови існування семантичного шару іiї загального інформаційного простору (а це властиво для сучасних КІС), наводить на думку про необхідність проведення періодичного (за розкладом або за запитом) моніторингу та, у разі необхідності, реінжинірингу часткових онтологій і їхніх відображень на загальновживану формальну онтологічну модель КІС. При цьому під час внесення деяких змін існує ймовірність ушкодження узгодженості та цілісності всього семантичного шару.

\section{Мета роботи}

Метою роботи є визначення джерел виникнення змін та основних процесів, а також імовірних наслідків, які пов'язані із внесенням змін до часткових онтологій, що описують IT-ресурси КІС.

\section{Анаміз стану проблеми}

Часткова семантична модель зазвичай надає деяку структуру знань певної ПрО та формалізується у вигляді орієнтованого графа, вершини якого - поняття, а дуги - взаємовідносини між ними. За поняття виступають інформаційні об'єкти, яким відповідають абстрактні або конкретні об'єкти, події, властивості, операції, а взаємовідносинами є іменовані зв'язки різного типу.

Побудова результуючої онтології з кількох вихідних, що стосуються різних ПрО або різних семантичних моделей однієї і тієї ж ПрО, під час інтеграції здійснюється на основі результатів порівняння концептів, взаємовідносин та атрибутів. Завдання інтеграції при цьому зводиться до побудови відображень і встановлення взаємозв'язків інтегрованих схем, тобто збереження відповідності множини онтологій заданому набору семантичних залежностей, що дозволяє встановити взаємодію між ними.

Для забезпечення семантично коректної узгодженості неоднорідних часткових онтологій, у контексті загального інформаційного простору КІС, необхідно 3'ясувати їхню спільність і відмінності, узгодити неоднорідні онтологічні специфікації і, вже на базі взаємної відповідності онтологічних контекстів, здійснювати перетворення і обробку інформаційних об'єктів.

Одна із суттєвих проблем усунення семантичної невідповідності часткових онтологічних моделей IT-ресурсів семантичного шару загального інформаційного простору КІС полягає в тому, що окремі зміни певної часткової онтології можуть вимагати рекурсивного повторення процесу внесення змін у залежні від модифікованої онтології інші семантичні описи корпоративних IT-ресурсів (часткові та загальні онтології, схеми баз даних, бази метаданих, корпоративні та користувацькі переліки ключових слів).

Зважаючи на те, що цей процес є доволі довготривалим і ресурсномістким, а також те, що наразі він переважно виконується експертами з управління знаннями вручну, для полегшення внесення змін до онтологій і уникнення можливих помилок унаслідок «людського фактору», важливо повністю або частково автоматизу- 
вати всі завдання, побудувавши певний технологічний ланцюг процесу відстеження та внесення змін, який може відбуватися за запитом, або за розкладом.

Проведений аналіз ряду наукових оглядів [13-15], що присвячені дослідженням з розв'язання визначеної проблеми, та наявним у доступі засобам управління семантичними моделями, висвітлив наступні важливі аспекти. Переважна більшість засобів управління онтологіями зорієнтована на процеси первинного створення семантичних моделей, вони передбачають переважно режим ручного введення даних і не передбачають ані моніторингу ступеню відповідності формальної онтологічної моделі КІС реальному стану системи, ані режимів автоматичного усунення семантичної неузгодженості. Отже, дослідження в напрямку автоматизованого підходу до актуалізації семантичного шару КІС у часі, залишаються актуальними і наразі продовжуються в наукових установах світу.

\section{Ажерела виникнення та типи змін в онтології.}

Узагальнено можна визначити 4 джерела змін семантичного шару КIC:

- IT-середовище, в якому працюють системи, може змінюватися, тим самим, припущення, що зроблені при побудові системи, стають недійсними;

- користувачі, вимоги яких часто змінюються після побудови системи, що вимагає адаптації системи;

- внутрішні процеси, якщо застосунки або структури даних, які пов'язані 3 робочими процесами, вимагають постійного реінжинірингу для досягнення вагомих результатів діяльності;

- зовнішні процеси, якщо змінюються зовнішні умови (регламенти, законодавства тощо) експлуатації КІС, які вимагають технологічних, інформаційних або інших змін у роботі системи.

Отже, запити на внесення змін до онтології спричиняються:

- модифікаціями у застосунках або в технології організації процедур і процесів обробки даних;

- впровадженням додаткової функціональності відповідно до зовнішніх обмежень або змін потреб користувачів;

- кращою організацією інформації тощо.

\section{Процес внесення змін в онтології}

Внесення нового терміну є найбільш частою зміною в будь-якій онтології, особливо це стосується тезаурусів і термінологічних словників. 3'являються нові поняття, і вони повинні бути розміщені в ієрархії термінів ПрО. При цьому потрібно відрізняти прості і агреговані терміни, адже новий агрегований термін може бути комбінацією двох або більше існуючих понять або, навпаки, новий термін уже є частиною існуючого агрегованого терміну.

Для загального випадку онтології значною складністю є внесення терміну зі зміненими властивостями. Це стається, коли поняття, що розглядається, вже є наявним в онтології, але його властивості і обмеження відрізняються від тих, які пов'язані з термінами, що вже існують.

Під час розміщення терміну в ієрархії термінів також можливі певні ситуації, що вимагають зміни ієрархії термінів, які виникають унаслідок різних підхо- 
дів до моделювання ПрО, коли один і той же термін фахівці з управління знаннями можуть віднести до різних рівнів ієрархії термінів у двох різних онтологіях.

Отже, зміна онтології відбувається, у загальному випадку, як відповідь на певну потребу, а саме:

— внесення нового терміну;

- внесення агрегованого терміну;

- внесення терміну, що має змінені співвідношення;

- внесення терміну, що має змінену ієрархію.

\section{ЗавАання процесу внесення змін Ао часткової онтології IT-ресурсу КIC}

Технологічний процес внесення змін до онтології IT-ресурсу КІС є своєрідною адаптацією до змін IT-архітектури КІС у часі і вимагає виконання наступних завдань:

— визначення наявності змін;

— подання змін;

— визначення семантики змін;

- поширення змін;

- впровадження змін;

— збереження змін;

- затвердження змін.

Поширені методи та підходи до виконання завдань зведено в таблицю, наведену нижче.

Методи та підходи до виконання завдань процесу внесення змін

\begin{tabular}{||l||l||}
\hline \multicolumn{1}{|c||}{ Завдання процесу внесення змін } & \multicolumn{1}{|c||}{ Методи та підходи } \\
\hline \hline \multirow{2}{*}{ Визначення наявності змін } & $\begin{array}{l}\text { Виявлення змін під час використання } \\
\text { Пиявлення змін на основі даних } \\
\text { Пиявлення змін на основі структурного аналізу змін }\end{array}$ \\
\hline Визначення семантики змін & $\begin{array}{l}\text { Онтологія RDF } \\
\text { Онтологія OWL } \\
\text { Онтологія процесу зміни }\end{array}$ \\
\hline Поширення змін & $\begin{array}{l}\text { Структурні, логічні та визначені користувачем } \\
\text { умови узгоженості онтології }\end{array}$ \\
\hline Впровадження змін & РUSH- і РULL-синхронізація \\
\hline Збереження змін & $\begin{array}{l}\text { Повідомлення про зміну } \\
\text { Використання змін }\end{array}$ \\
\hline \multirow{3}{*}{ Затвердження змін } & Ведення журналу змін \\
\hline & $\begin{array}{l}\text { Обгрунтування змін } \\
\text { Актуальність змін щодо онтології } \\
\text { Тестування, формальна перевірка, встановлення та } \\
\text { підтримка гарантованого рівня якості }\end{array}$ \\
\hline
\end{tabular}

Треба взяти до уваги, що підтримка цілісності семантичного шару КІС вимагає семантичної узгодженості як часткових, так і загальної онтологій, а це передбачає послідовне поширення змін до всіх інших семантичних IT-ресурсів, що 
використовують змінені онтології, отже процес може прийняти рекурсивний характер.

\section{Висновки}

Динаміка змін у часі нормативної бази, IT-ресурсів, змін в інформаційному середовищі КІС часто породжує зміни у вимогах до застосувань, технологічних процедур і даних, які, якщо вони були побудовані з урахуванням семантики, мають бути виконані лише разом з реінжинірингом відповідних базових онтологій семантичного шару КIC.

Задля підтримки семантичної сумісності процес внесення змін в одній із наявних часткових онтологій, має поширюватися на всі інші, що пов'язані або залежні від неї.

Процеси моніторингу відповідності та внесення змін задля актуалізації семантичного шару загального інформаційного простору КІС наразі або не виконуються, або виконуються фахівцями з управління знаннями вручну. Оскільки цей процес має довготривалий рекурсивний характер, важливо формалізувати процес і повністю або частково автоматизувати та інтелектуалізувати всі завдання цього процесу для уникнення можливих помилок, прискорення та полегшення роботи, а також для збереження цілісності і узгодженості всієї сукупності семантичного контексту.

1. Матов О.Я. Храмова I.О. Сучасні технології інтеграції інформаційних ресурсів. Реєстрачія, зберігання і оброб. даних. 2009. Т. 11, № 1. С. 33-42.

2. Храмова I.О. Адаптація розподілених інформаційних інфраструктур міжвідомчої взаємодії. Реєстрація, зберігання і оброб. даних. 2012. Т. 14, № 2. С. 59-66.

3. Матов О.Я., Храмова І.О. Проблеми горизонтальної інтеграції інформаційних ресурсів у багаторівневих організаційних структурах 3 динамічною конфігурацією. Реєстрачія, зберігання $i$ оброб. даних. 2007. Т. 9, № 3. С.88-97.

4 Матов О.Я., Храмова I.О. Динамічна інтеграція інформаційних ресурсів єдиної інформаційної інфраструктури ринку електроенергії. Функиіонування та розвиток ринків електроенергї̈ та газу: зб. наук. праць. Інститут проблем моделювання в енергетиці НАН України ім. Г.С. Пухова. Київ, 2006. С. 93-98.

5. Додонов О.Г., Коваль О.В., Глоба Л.С., Бойко Ю.Д. Комп’ютерне моделювання інформаційно-аналітичних систем: монографія/Київ: ІПРІ НАН України, 2017.

6. Popova M.A. Ontologiya vzayemodiyi v seredovishi geoinformacijnoyi sistemi [Ontology of interaction in the middle of the geographic information system: dissertation]. Kyiv. $240 \mathrm{p}$.

7. Holovin O.O. Zastosuvannia metodolohii transdystsyplinarnykh ontolohii $\mathrm{v}$ informatsiinoanalitychnii systemi pidtrymky protsesiv osnashchennia ozbroienniam ta viiskovoiu tekhnikoiu [Application of methodology of transdisciplinarity ontology in information-analytical system for support processes with equipping of armament and military equipment], Systems of Arms and Military Equipment. 2019. No. 3(59). P. 17-24. https://doi.org/10.30748/soivt.2019.59.02.

8. Holovin O.O. Taksonomichne vidobrazhennia informatsiinykh resursiv doslidnokonstruktorskykh robit. Наука і техніка Повітряних Сил Збройних Сил України. 2020. № 2(39) ISSN 2223-456X [Taxonomic display of information resources of research and development works]. Weapons and military equipment. 2019. No. 4(24). P. 12-21. https://doi.org/1034169/2414-0651.2019.4(24).

9. Ландэ Д.В., Снарский А.А. Подход к созданию терминологических онтологий. Научный журнал «Онтология проектирования» 2014. 2(12).

10. Zhang L., Ren J., Li X. OIM-SM: A method for ontology integration based on semantic apping. Journal of Intelligent and Fuzzy Systems. 32 (3) (2017) 1983-1995. doi:10.3233/JIFS-161553. 
11. Ochieng P. Large Scale Ontology Matching: State of the Art Analysis. ACM Computing Surveys. 51. 10.1145/3211871.

12. Doing-Harris, K.M., Yarden, L., Meystre, S.M. Automated concept and relationship extraction for the semi-automated ontology management (SEAM) system. Journal of Biomedical Semantics. 6 (2015): n. pag.

13. Khattak A.M., Batool R., Pervez Z., Khan A.M., and Lee S. Ontology evolution and challenges. J. Inf. Sci. Eng. 2013. Vol. 29, No. 5. P. 851-871.

14. Noy N., Kunnatur S., Klein M., Musen M. Tracking changes during ontology evolution. InProc.of Int. Semantic Web Conference (ISWC 2004). 2004. P. 259-273.

15. Nguyen A., Gardner L., Sheridan D. Towards ontology-based design science research for knowledge accumulation andevolution. In Proceedings of the Hawaii International Conference on System Sciences, Honolulu, HI, USA, 8-11 January 2019. 